\title{
ICA contribution to the development of international standards of competence for nautical cartographers
}

\author{
Ron Furness, ${ }^{\mathrm{a}}$ Lysandros Tsoulos ${ }^{\mathrm{a}}$ \\ ${ }^{a}$ FIG/IHO/ICA International Board on Standards of Competence for Hydrographic Surveyors and Nautical Cartographers - IBSC, \\ ron.furness@gmail.com,lysandro@central.ntua.gr
}

\begin{abstract}
All professions face challenges as how best to ensure the achievement and continuance of the highest standards as they seek to determine and promulgate best practices. In the essentially linked professions of hydrographic surveying and nautical cartography these challenges become immediately international in their impacts and require close cooperation between the professional bodies representing surveyors, hydrographers and cartographers. The Standards of Competence for Nautical Cartographers are known in short form as S-8 and they describe the minimum required competencies for nautical cartographers. They indicate the minimum degree of knowledge and experience considered necessary for nautical cartographers and provide a set of programme outlines against which the FIG/IHO/ICA International Board on Standards of Competence for Hydrographic Surveyors and Nautical Cartographers may evaluate programmes submitted for recognition. The Standards recognize two levels of competence: Cate- gory A and Category B. In nautical charting communities, Category A programmes offer levels of comprehensive and broad-based knowledge in all aspects of the theory and practice of nautical cartography. Category B programmes provide a level of practical comprehension, along with the essential theoretical background, necessary for individuals to carry out the various nautical cartography tasks. The Standards have recently undergone complete review and should be ratified during 2017/18. This paper aims to bring the existence and aims of the Standards to the wider notice of ICA members and to describe the philosophy and aims of the review in meeting the professional competency needs of the nautical cartographic community.
\end{abstract}

Keywords: Nautical cartography, Standards of competence, Standards development, Programme recognition

\section{Introduction}

As noted above, all professions face challenges as how best to ensure the achievement and continuance of the highest professional standards as they seek to determine and promulgate best practices. In the essentially linked professions of hydrographic surveying and nautical cartography these challenges become immediately international in their impacts and require close cooperation between the professional elements. Thus, to achieve these objectives, the three international organizations representing surveyors, hydrographers and cartographers, have developed Standards of Competence that institutions or professional bodies may adopt for their educational or training programmes and competency schemes. The three organizations are: Fédération Internationale des Géomètres (FIG); International Hydrographic Organization (IHO) and International Cartographic Association ((ICA) through its Working Group on Marine Cartography.

During the International Congress of Surveyors (FIG) at Wiesbaden in 1971, a Working Group (WG) was formed by its Commission IV (Hydrography) to develop international standards of competence within the profession of surveying at sea. In 1972, during the International Hydrographic Conference in Monaco, the IHO set up a working group for the compilation of training programmes in hydrography conducted by its Member States. In 1974, at the XIV FIG Congress in Washington, it was resolved that the FIG and IHO working groups would combine to study and modify the Report of the FIG WG on educational standards.

The Report of the joint FIG-IHO WG was accepted by the two parent bodies at their respective conferences in 1977. In consequence of similar resolutions passed at these conferences an International Advisory Board on Standards of Competence for Hydrographic Surveyors (the Board) was formed. The Board met annually and compiled and regularly updated the "Standards of Competence for Hydrographic Surveyors". The intention of the Board in preparing these Standards was to provide guidance whereby individual surveyors might be trained and qualified in accordance with internationally accepted levels of competence. Institutions and professional bodies made submissions to the Board seeking its recognition that such submissions met the published minimum Standards of Competence.

Standards of Competence for Nautical Cartographers: At the Second Extraordinary Conference of the IHO in March 2000, the development of a set of Standards of Competence for Nautical Cartographers was approved. It was agreed that the FIG/IHO International Advisory Board on Standards of Competence for Hydrographic Surveyors would be the appropriate body to lead the preparation of these Standards, together with the contribution of the International Cartographic Association (ICA). The authors subsequently joined the Board as full members since 2002 . 
Recognizing the ICA contribution, the Board changed its name to the FIG/IHO/ICA International Advisory Board on Standards of Competence for Hydrographic Surveyors and Nautical Cartographers. The Secretariat is provided by the International Hydrographic Bureau. In 2009 the name of the Board was changed to its current title: the FIG/IHO/ICA International Board on Standards of Competence for Hydrographic Surveyors and Nautical Cartographers (IBSC).The IBSC comprises ten (10) Members representing the three parent organizations: FIG (4); IHO (4); and ICA (2).

\section{Standards development}

The Standards of Competence for Nautical Cartographers (the Standards) are known in short form as S-8 and they describe the minimum required competencies for nautical cartographers. They indicate the minimum degree of knowledge and experience considered necessary for nautical cartographers and provide a set of programme outlines against which the IBSC may evaluate programmes submitted for recognition. In 2008 the recognition period of programmes which had been ten (10) years was reduced to six (6) years, with a transitional period for the existing recognised programmes.

The Standards recognize two levels of competence: Category A and Category B. In both the hydrographic and nautical charting communities, Category A programmes offer levels of comprehensive and broadbased knowledge in all aspects of the theory and practice of hydrography or nautical cartography. Category B programmes provide a level of practical comprehension, along with the essential theoretical background, necessary for individuals to carry out the various hydrography or nautical cartography tasks.

Since its inception, the IBSC has developed and published three editions of the S-8 Standards. These editions reflect the scientific and technological developments in the fields of cartography and include considerable improvements in the submission, delivery and review procedures of the programmes. Editions of the Standards to and including Edition

3.1.0 were structured so that Category B programmes provided technical education to support a set of fundamental and practical competencies. Initially, Category A educational programmes included all Category B competencies plus additional detailed-level competencies. This meant that Category B was a subset of Category A.

The Third Edition synchronized procedures with those adopted by the IBSC for all its Standards of Competence and updated some of the requirements. It recognised that many production organisations are transitioning from traditional to completely digital production processes.

The domination of digital cartography and the increasing use of and reliance on software systems and packages does not reduce or obviate the need for education and training in what might be termed "traditional" cartographic skills, knowledge and principles. If anything, the need is greater, since there have been many instances where an over- reliance on packages frequently results in less than desirable maps/charts. Successful nautical cartographers come from many related areas they might be straight from school with some training in cartography, ex-navigators, naval officers, geodesists, geographers, drafts-persons, GIS trained persons, software developers, land-mappers, surveyors, hydrographic surveyors -from almost any geo-focussed area or discipline.

In present times, many of the traditionally accepted skills of the nautical cartographer remain absolutely essential

- attention to detail, ability to synthesise numerous different data sets, critical analysis of geographic data, awareness of the critical nature of the product and the reliance placed on it by the user at sea, the environment in which the product is made and also used, a flair for cartographic design, adherence to specifications, an openness to adapting available technologies and working to time-critical deadlines. These are not exclusive, but representative.

Additionally, nautical cartographers, at least those at a senior level, must be capable project managers, able to contribute to tender and project requirement documents, analyse tender responses, justify business cases in the charting context and deliver their final product utilising both public and private sector capabilities.

The Third Edition included a new and expanded section relating to the Recognition of Schemes that maintain the competency of individuals beyond their formal training and educational qualification.

In 2013 the IBSC decided on a number of changes pertaining to the introductory part of the S-8 and its Appendices. These changes relate to improvements concerning the internal and the on-site review process of the programmes, their duration and special requirements for programmes including e-learning components.

\section{Separation of Categories}

It became evident to the IBSC that there were influencing factors that brought to the fore a number of imperatives for it to change the way hydrographic surveyors and nautical cartographers are educated. To adapt to these new challenges, methodologies, equipment and software, the IBSC agreed on the separation of Category A and Category $B$ requirements and a future separate path of development for each category.

Development rationale: The motivation behind the separation of the Category A and Category B requirements and the intended outcome of Category $\mathrm{A}$ and Category B education/training is as follows: a Category A programme will introduce subjects from the beginning at the underlying principles level and a Category B programme will introduce subjects from a practical level. According to the above framework the Category B Standard will be aimed at the basic educational and training requirements for nautical cartographers (S-8). The Category A Standard will be aimed at the theoretical educational and foundational background necessary for nautical cartographers in- 
charge and cartographic managers who will develop specifications for nautical charts, establish quality control and quality assurance systems, and respond to the specific requirements of a full range of cartographic projects.

For both Category A and Category B Standards, the ability to examine and synthesize hydrographic surveys and utilize hydrographic and/or cartographic databases to compile and produce nautical charts and other marine oriented cartographic products are essential competencies, and thus a key part of education and training needs to be through the application of laboratory and applied work (practical exercises and final project).

The educational process itself is in turn influenced by changing technological and methodological imperatives. Connectivity and the introduction of so-called e-learning methods and blended learning techniques have naturally attracted the attention of the professional community. Another relevant issue is the educational approach in the development of the Standards relating to the principles of the style in which the requirements are presented. The IBSC adopted the concept and principles of constructive alignment that are used in most academic institutions and are documented in educational texts (Biggs and Tang 2007). The Standards describe Intended Learning Outcomes (ILO's) using verbs that are detailed under Bloom's taxonomy (Anderson, L.W et al. 2001, Bloom, B.S. (Ed.) 1956). In principle, an institution will evaluate students to ensure that they have achieved each learning outcome. The separation of Category A and Category B Standards in addition to the adoption of constructive alignment approach was approved in 2013.

In addition, options will be removed at the Category A \& B levels. In defining competencies in terms of ILO's, the opportunity will exist for institutions to focus attention on specific issues while adhering to competencies and associated content as described in the Standards. Thus, while core competencies are retained, institutions can offer unique programmes within this framework, directed towards specific needs. At the Category A level, it is intended to introduce so-called "Foundation Subjects", which potentially will permit recognition of a student's advanced standing from prior qualification at a more general, but directly relevant, level.

\section{Structure of the Standards}

A programme consists of SUBJECTS (Basic or Essential for Category B or Basic, Foundation Science or Nautical Cartography Science for Category A). Submissions for recognition may seek to justify exemptions for BASIC or FUNDAMENTAL subjects, but must cover and teach ESSENTIAL subjects.

Each SUBJECT comprises a list of TOPICS and the TOPICS contain ELEMENTS. For example, the SUBJECT E7 "Nautical Cartography" contains the TOPIC E7.1 "The Nautical Chart" that has the ELEMENTE7.1a "Evolution of nautical charts" (see Tables 1 and 2 below).

This approach does not constrain the design of any submission but the submissions must relate the subjects and coverage of their content to the relevant Standard and a table template is provided to assist this requirement. The table directs each programme to relate the Standard to each of the programme's own subjects or courses and to detail the time allocated for each of the elements for Theory, Practical Learning and Self-Guided study.

It is important to understand that each TOPIC and/or ELEMENT is associated with:

- One or more intended LEARNING OUTCOMES that a student should be able to achieve on completion of the programme. All LEARNING OUTCOMES should be assessed. This may be done through one of, or a combination of, the following: examination, assessed exercise or presentation, laboratory report or final project work.

- A CONTENT list. This list is associated with one or more LEARNING OUTCOMES and describes the theoretical knowledge or practical/technical context which the course syllabi should address to meet a particular LEARNING OUTCOME.

Bloom's taxonomy (Bloom, B.S. (Ed.) 1956, Anderson, L.W. et al. 2001) has been applied to describe each intended learning outcome of the Standards and the associated verbs are an indication of the expected level of knowledge. One of the three following levels of knowledge is associated with each element of the Standards.

Basic - Basic knowledge of the subject provides familiarity with the concepts. Active verbs (indicating recall, recognition and comprehension of materials) associated with learning outcomes are: define, identify, describe, explain, differentiate, predict.

Intermediate - Knowledge of the subject as far as theory and principles are concerned, sufficient to enable their application in practice in all common hydrographic and nautical cartography tasks. Active verbs (indicating application and analysis) associated with learning outcomes are: apply, use, calculate, solve, classify, analyze.

Advanced - Thorough knowledge of the subject in all its aspects to enable its application in all hydrographic and nautical cartography activities including the most difficult areas. Active verbs (indicating synthesis and evaluation) associated with learning outcomes are: evaluate, select, design, specify, plan and create.

Category "B" programmes are intended to deliver Basic and Intermediate levels of knowledge and Category "A" programmes are intended to deliver Basic, Intermediate and Advanced levels of knowledge.

Duration of programmes: At the Category A level, the length of a programme will be around 40 weeks including a major and comprehensive cartographic project. At the Category B level, a programme will be around 24 weeks including a major project. A Category A programme must be completed within six years and a Category $B$ programme within five years. 


\subsection{Practical exercises and final project}

Because hydrography and nautical cartography are applied disciplines, every student undertaking a Category "A" or Category "B" Programme is expected to receive hands-on experience under direct supervision of the instructors. This experience should form an important part of the student's assessment and should be considered in two parts, practical exercises and a final project.

Practical Exercises: Both Category "A" and Category "B" programmes should contain practical hydrographic surveying or nautical charting exercises related to modules. These should include, for example: experiments, exercises, laboratory work and fieldwork designed to complement the theory component.

Final Project: Any qualifying programme should also include a minimum period of at least four (4) weeks devoted to a supervised comprehensive final project. These projects should reflect the level of the overall knowledge outlined in the programme, and a full report should be compiled by students. Assessment of intended learning outcomes associated to this project is an important factor and an evaluation scheme for the final project must consider alignment for individual students.

The Comprehensive Cartographic Project (CCP) for a Category "B" nautical charting programme will exercise the skills of the students to carry out the various nautical charting tasks.

Revision of the Standards: Revision of the Standards is an ongoing process and the Standards are considered for change or amendment at each annual meeting of the Board. The Board issues amended versions regularly.

Example comparing a Category A and B subject:

\begin{tabular}{|c|c|c|}
\hline \multicolumn{3}{|c|}{ E7: Nautical Cartography } \\
\hline \multicolumn{3}{|c|}{ E7.1 The Nautical Chart } \\
\hline $\begin{array}{l}\text { Elemen } \\
\mathrm{t}\end{array}$ & Content & $\begin{array}{l}\text { Learning } \\
\text { outcomes }\end{array}$ \\
\hline $\begin{array}{l}\quad \text { E7.1a } \\
\text { Evolution } \\
\text { of } \\
\text { nautical } \\
\text { charts } \\
\\
\text { (I) }\end{array}$ & $\begin{array}{l}\text { (i) Paper (national } \\
\text { (ii) and INT) } \\
\text { (iii) ENC (ECDIS) } \\
\text { ECS }\end{array}$ & \begin{tabular}{l}
\multicolumn{1}{c}{ Outline } \\
the \\
evolution of \\
nautical \\
charts and \\
chart \\
systems.
\end{tabular} \\
\hline $\begin{array}{l}\text { E7.1b } \\
\text { Nautical } \\
\text { charts }\end{array}$ & $\begin{array}{l}\text { (i) Planning } \\
\text { (ii) Navigation } \\
\text { (iii) Typ } \\
\text { (iv } \text { is of } \\
\text { ) } \text { hart } \\
\text { ' } \\
\text { Jhart } \\
\text { eadi } \\
\text { lg }\end{array}$ & $\begin{array}{l}\quad \text { Classify } \\
\text { various } \\
\text { types of } \\
\text { nautical } \\
\text { charts } \\
\text { according } \\
\text { to their } \\
\text { primary } \\
\text { purpose. }\end{array}$ \\
\hline
\end{tabular}

\begin{tabular}{|c|c|c|}
\hline & & $\begin{array}{l}\text { Analyze } \\
\text { various } \\
\text { types of } \\
\text { charts } \\
\text { and their } \\
\text { uses. }\end{array}$ \\
\hline $\begin{array}{l}\text { E7.1c } \\
\text { Nautical } \\
\text { chart } \\
\text { design } \\
\quad \text { (I) }\end{array}$ & $\begin{array}{l}\text { (i) Characteristics } \\
\text { (ii) Content } \\
\text { (iii) Terminology } \\
\text { (iv Symbolization } \\
\text { ) Sym }\end{array}$ & $\begin{array}{l}\quad \text { Describe } \\
\text { present day } \\
\text { characteristi } \\
\text { cs and } \\
\text { design } \\
\text { principles of } \\
\text { nautical } \\
\text { charts. }\end{array}$ \\
\hline & & $\begin{array}{l}\text { Describe } \\
\text { the impact } \\
\text { of } \\
\text { technology } \\
\text { on nautical } \\
\text { chart design } \\
\text { and } \\
\text { production. }\end{array}$ \\
\hline $\begin{array}{l}\quad \text { E7.1d } \\
\text { Nautical } \\
\text { chart } \\
\text { reference } \\
\text { framewo } \\
\text { rk } \\
\quad \text { (I) }\end{array}$ & $\begin{array}{l}\text { (i) Chart graticule } \\
\text { (ii) Chart grid }\end{array}$ & $\begin{array}{l}\quad \text { Compute } \\
\text { and prepare } \\
\text { chart } \\
\text { graticule } \\
\text { and chart } \\
\text { grid using } \\
\text { appropriate } \\
\text { software } \\
\text { according to } \\
\text { specification } \\
\text { s. }\end{array}$ \\
\hline
\end{tabular}

Table 1: Extracted table example from S-8B

For students of a S-8 Category "A" Programme, a Complex Final Cartographic Project (CFCP) is required, which will include analytical reasoning, decision making and development of solutions to non-routine problems. The Complex Final Cartographic Project must be described in detail and is intended to reflect the level of the overall knowledge outlined in the programme, and a full report should be compiled by students. Assessment of intended learning out- comes associated to this project is an important factor and an evaluation scheme for the final project must consider alignment for individual students.

Examination of the two tables reveals that, at the Category B level, the levels of knowledge for each of the four ELEMENTS is set at Intermediate (I) (see first column for each ELEMENT). In Table 2, the levels of 
knowledge expected for each ELEMENT is set to Intermediate (I) for ELEMENTS E7.1(a) and E7.1(b) but at Advanced (A) for ELEMENTS E7.1(c) and E7.1(d). Additionally, for the latter two ELEMENTS at the Advanced level of knowledge, the associated verbs are at the appropriate level. "Describe" becomes "Specify" or "Analyze". There are changes also to content.

The two examples used are simple ones. Examination by the keen reader of the full Standards is encouraged in order that the overall depth and complexity, as well as subtleties, of the content can be fully appreciated. Both Category A and Category B drafts are available for download from IHO Publications (2017 a \& b).

\begin{tabular}{|c|c|c|}
\hline \multicolumn{3}{|c|}{ E7: Nautical Cartography } \\
\hline \multicolumn{3}{|c|}{ E7.1 The Nautical Chart } \\
\hline $\begin{array}{l}\text { Elem } \\
\text { ent }\end{array}$ & Content & $\begin{array}{l}\text { Learning } \\
\text { outcome } \\
\mathrm{S}\end{array}$ \\
\hline $\begin{array}{l}\quad \text { E7.1a } \\
\text { Evolutio } \\
\text { n of } \\
\text { nautical } \\
\text { charts } \\
\quad \text { (I) }\end{array}$ & $\begin{array}{l}\text { (i) Paper } \\
\text { (national and } \\
\text { INT) } \\
\text { (ii) ENC } \\
\text { (ECDIS) (iii) } \\
\text { ECS. }\end{array}$ & $\begin{array}{l}\quad \text { Outline } \\
\text { the } \\
\text { evolution } \\
\text { of nautical } \\
\text { charts and } \\
\text { chart } \\
\text { systems. }\end{array}$ \\
\hline $\begin{array}{l}\text { E7.1b } \\
\text { Nautical } \\
\text { charts } \\
\text { (I) }\end{array}$ & $\begin{array}{l}\text { (i) Planning/sche } \\
\text { ming } \\
\text { (ii) The use of } \\
\text { charts in navigation } \\
\text { (iii) Types of } \\
\text { charts (iv) Chart } \\
\text { reading. }\end{array}$ & $\begin{array}{l}\quad \text { Identify } \\
\text { and } \\
\text { classify } \\
\text { various } \\
\text { types of } \\
\text { nautical } \\
\text { charts and } \\
\text { their } \\
\text { content } \\
\text { according } \\
\text { to their } \\
\text { primary } \\
\text { purpose. }\end{array}$ \\
\hline $\begin{array}{l}\text { E7.1c } \\
\text { Nautical } \\
\text { chart } \\
\text { design } \\
\quad \text { (A) }\end{array}$ & $\begin{array}{l}\text { (i) Design principles } \\
\text { for nautical charts } \\
\text { (ii) Characteristics } \\
\text { (iii) Content (iv) } \\
\text { Terminology } \\
\text { (v) Symbolization. }\end{array}$ & $\begin{array}{l}\quad \text { Specify } \\
\text { present day } \\
\text { characterist } \\
\text { ics and } \\
\text { design } \\
\text { principles } \\
\text { of nautical } \\
\text { charts. } \\
\text { Analyze } \\
\text { the impact } \\
\text { of } \\
\text { technology }\end{array}$ \\
\hline
\end{tabular}

\begin{tabular}{|c|l|l|}
\hline & & $\begin{array}{l}\text { on nautical } \\
\text { chart } \\
\text { design and } \\
\text { production. }\end{array}$ \\
\hline $\begin{array}{l}\text { E7.1d } \\
\text { Nautical } \\
\text { referenc } \\
\text { e } \\
\text { framewo } \\
\text { rk }\end{array}$ & $\begin{array}{l}\text { (i) } \\
\text { Chart } \\
\text { gratic } \\
\text { ule (ii) } \\
\text { Chart } \\
\text { grid. }\end{array}$ & $\begin{array}{l}\text { Specify, } \\
\text { compute } \\
\text { and prepare } \\
\text { chart } \\
\text { graticules } \\
\text { and chart } \\
\text { grids using } \\
\text { appropriate } \\
\text { software. }\end{array}$ \\
\hline
\end{tabular}

Table 2: Extracted table example from S-8A

\section{Procedure for recognition of a programme}

An institution or company is invited to submit their designed course against the relevant Standard (A or B) to the Board before 31st December each year for consideration at the Board's next plenary meeting usually held before 30th April in the following year. Usually with some iteration between the submitting organization and the Board, the submission is recognized, recognized subject to meeting some conditions defined by the Board or not recognized.

The detailed guidance for submitting institutions to assist in their programme preparation and submission is published by the IHO as a companion document to the Standards entitled "Guidelines for the Implementation of Standards of Competence for Hydrographic Surveyors and Nautical Cartographers" IHO Publications (2017 c) .

\subsection{Internal review}

Institutions are required to have in place an internal review process for the Programme. It is recommended that any Programme will also undergo a comprehensive internal review every 3-5 years, to address any issues that may arise

and to update course content. The methodology adopted by the institution for the internal review will need to be furnished in detail. The summary of any recent internal review undertaken for a programme submitted for recognition will need to be included in the submission.

This should not be taken as precluding newly developed programmes not yet able to satisfy these items. The Board wishes to see how feedback from all sources, including students, is formally taken into account within and by the Programme.

\subsection{Student feedback}

The IBSC strives to ensure that quality control measures are in place and a part of this process involves consultation with the student body. It is important that 
students passing through the Programme are able to contribute to development and change. Mechanisms such as student liaison meetings help in dealing with issues that arise during delivery. On completion of the Programme a questionnaire should be circulated to solicit opinions on matters such as accessibility to resources and delivery of each course. Summary results from questionnaires should be included in the sub- mission.

\subsection{Programme reviews and on-site visits}

Institutions with recognized programmes should be prepared to allow an IBSC visit, to view the facilities and to meet staff and students involved. The guidelines for the IBSC visit are: A programme review is a process for evaluating and continuously enhancing the quality and currency of programmes. The evaluation is conducted through a combi- nation of self-assessment, followed by peer on-site consultation by the IBSC, for the mutual benefit of all parties. In addition, a visit serves to raise the profile of hydrography and nautical cartography with other in-country agencies and regionally.

\section{Conclusions}

All components of the nautical cartography profession face challenges as to how best to ensure the continuance of high standards and how best to ensure the continuation of best practices based on minimum standards of competence world-wide.

The IBSC believes that the new version of Standards of Competence for Nautical Cartographers serve their purpose and will deliver authoritative guidance to the pertinent institutions around the world to prepare, submit and deliver programmes that will be to the benefit of the international nautical charting community for the foreseeable future.

\section{Acknowledgements}

We acknowledge the contributions of the entire IBSC membership to the overall development of the Standards.

\section{References}

Anderson, L.W., Krathwohl, D.R., Airasian, P.W., Cruikshank, K.A., Mayer, R.E., Pintrich, P.R., Raths, J., Wittrock, M.C. (2001). A Taxonomy for Learning, Teaching, and Assessing: A revision of Bloom's Taxonomy of Educational Objectives. New York: Pearson, Allyn \& Bacon.

Biggs and Tang (2007). Teaching for Quality Learning at University, Open University Press (3rd Edition).

Bloom, B.S. (Ed.). Engelhart, M.D., Furst, E.J., Hill, W.H., Krathwohl, D.R. (1956). Taxonomy of Educational Objectives, Handbook I: The Cognitive Domain. New York: David McKay Co Inc.IHO Publications (2017):
a) $\mathrm{S}-8 \mathrm{~A}$
Draft

1.0.0.http://iho.int/iho_pubs/draft_pubs/S-8/S-

8A_draft_Ed1.0.0.pdf. Accessed 18 Feb. 2017.

b) S-8B Draft
1.0.0.http://iho.int/iho_pubs/draft_pubs/S-8/S-
8B draft Ed1.0.0.pdf. Accessed 18 Feb. 2017. c) S-5 - $\quad \mathrm{S}-8 \quad$ Draft $\quad$ Ed. 1.0.0. http://iho.int/iho_pubs/draft pubs/S-5_S-8/S5 S-8-Guidelines.pdf. Accessed 18 Feb. 2017. 